\title{
HEALTH OF ADULTS THROUGH PRISM OF PHYSICAL ACTIVITY
}

\author{
Elena Bendíková ${ }^{1}$, Beáta Dobay ${ }^{2}$ \\ ${ }^{I}$ Department of Physical Education and Sport, Faculty of Arts, Matej Bel University in Banská Bystrica, \\ Slovakia \\ ${ }^{2}$ Department of Physical Education and Sports, Selye Janos University in Komarno, Slovakia
}

Summary: The aim of the research was to find out the realization of the physical activity among the middle-aged adults by the association with their health, retrospective of the factor contributing to the transfer of the physical activity to the adulthood. The monitored group consisted of 742 respondents of the middle-aged adults from the Southern Districts of Slovakia, of which 403 were the women (age = $37.2 \pm 3.04$ years) and 339 were the men (age $=36.5 \pm 4.54$ years) as the selection was deliberate. The monitoring was conducted by the three stages in 2014, through the so-called "Egészség és mozgás" "Health and Movement" standardized, anonymous questionnaire, which consisted of 60 questions. Our findings point to the stated facts. The findings found the relationship between the health and fitness among the men $(\mathrm{r}=0.8300)$, as well as among the women $(\mathrm{r}=0.7193)$. The relationship between the physical activity and the feeling of health was recorded only among the men $(r=0.8921)$, while the relationship between the health problems and the feeling of health was also found among the men $(r=$ 0.739), as well as among the women $(r=0,6714)$. At the same time, the men perceive the importance of the physical activity, in terms of their health condition $(r=0.8791)$ more intense than the women. The physical education was significantly $\left(\chi^{2}=112.47, \mathrm{p}<0.01\right)$ among the men $(67.6 \%, \mathrm{n}=229)$, opposite to the women $(33.7 \% ; \mathrm{n}=136)$ contributed to the transfer of the physical activity from the school environment to the adulthood. The stated findings show that the targeted education of the population, even from the childhood with the other effective, preventive measures is very important.

Key words: Adulthood, education, physical activity, physical education, health.

DOI 10.2478/afepuc-2018-0005

(C) Acta Facultatis Educationis Physicae Universitatis Comenianae 


\section{Introduction}

A current lifestyle of a human being has acquired a hypokinetic character, which has been manifested in the human beings movement regime, where an inadequate recommended volume of a physical activity generates favorable inputs and impulses to emergence of "civilization diseases", which have far-reaching consequences for a health of the human being (Prasad \& Das 2009). Corbin \& Pangrazi (2003) in this context, suggest that not only the volume of the physical activity of the human being is reduced but also the intensity as well.

The issues about a physical ability, in relation with the health, are at the beginning of our millennium one of the most up-to-date issues of a modern society. Foreign and domestic studies confirm that we have less movement than previous generations, as a result of which a level of the physical abilities decreases, a resistance of an organism to the diseases is reduced, an immunity of the organism is disturbed with a consecutive origin of health disorders, which results in economic consequences for a country itself, in terms of social and health insurance companies. The physical activity, in relation to a quality of life, lifestyle and health, shows close relationships (Nowak 1997). Pate \& O'Neill (2008) agree with the stated facts, as well as suggest that a lack of physical activity significantly influences not only the physical ability and performance of the human being but also his/ her work performance and health condition (Borbély \& Müller 2008; Blair et al. 2010; Nemček 2016; Nemček \& Simon 2016).

In Slovakia is recorded a decline of the physical ability, not only among school but also among adult population, which is associated with a rising character of the health disorders. This is also evidenced by the health insurance statistics, where more than $60 \%$ of the human beings target to a treatment of cardiovascular diseases, $20 \%$ to a treatment of respiratory diseases, $15-18 \%$ to a treatment of metabolic diseases, which have a rising tendency in the last two decades, not excluding disorders of musculoskeletal system (Pedersen 2009; Tomková \& Palaščáková-Špringrová 2013; Gurín et al. 2016; Bendíková et al. 2016; Nemček 2017a, b).

A prevalence in Slovakia has recorded vertebrogenic diseases since 1990, which IASP (1990) defines as acute and chronic recurrent, persistent and painful spine conditions of degenerative or functional etiology, where a back pain is a symptom, not the disease itself, occurring in a childhood and an adolescence, manifesting in an adulthood as the vertebrogenic diseases which:

- are the main cause of the human beings incapacity for the work at 35 - 45 years of age, 
- are placed in the $5^{\text {th }}-6^{\text {th }}$ place in a cause of hospitalization,

- $60-90 \%$ of the population had or have had vertebrogenic problems,

- within rehabilitation ambulances, $70 \%$ of the patients in Slovakia have difficulties with the spine. This is the serious economic problem.

In Slovakia is currently 1.5 to 2 million overweight or obese human beings, of which up to $10 \%$ (around 200000 ) suffer from the highest degree of a disability and severe morbid obesity. The overweight and obesity with aging among men and women are increasing and by the age of 64 , on average $47 \%$ of the human beings have the overweight and $20 \%$ of the human beings have the obesity. Risk factors of overall cholesterol have in Slovakia $43 \%$ of the men and $40 \%$ of the women of a productive age. The evident is increasing trend of a morbidity, based on diabetes mellitus II, in which since 2000 the number of treated diabetics increased by $27 \%$. The most vulnerable age group is between $50-69$ years of age. At the age of 36 - 45 years, a hypertension is reported among $28 \%$ of the men and $16 \%$ of the women, as joint and spinal pains are ranging from $50 \%$ to $80 \%$ of the adult population. A cause of an ascending trend of the mentioned diseases among the adult population is: lack of physical activity, unhealthy eating, obesity and stress.

One of the priority tasks, which is throughout the life of human being is a health care (WHO 2005), while from each side is information "attacking" us about the healthy lifestyle. Despite, the lifestyle, in which there is no movement, has become an all-society problem, not excluding the adult population. The health is a category, which protection is also written in legislation. In Slovakia, it is the Act No. 355/2007 on Protection, Support and Development of Public Health The health has a multi-factor bio - psycho - social basis. While in the past, the health has been determined predominantly by an influence of biological patterns, it is now more and more clearly conditioned by social factors. The health cannot be obtained as genetically given unchangeable status. The genetic basis is only a biological potential, which can evolve in a positive or negative direction.

Bendíková (2014) states that a basis of this situation is an understanding of an importance of the health benefits and essence of the physical activity, in terms of its monitoring and subsequent intervention in a school environment, through a prism of physical and sport education, which directly and indirectly creates space for a diversification and realization of an innovative content of classes. A liberalization of the contents of a curriculum of the physical and sport education puts teachers of the physical and sport education increased demands, even in a selection of new and nontraditional physical activities, and thus the space to diversify an offer of the physical activities (Bendíková 2016a). A benefit, should be classes 
within the school educational curriculum of varied character (exercises with fitballs, overballs, expanders, bosu balls, flowin, pilates, zumba, floorball, badminton, rope and so on), which has a positive effect on the physical, functional, social and psychological development of a pupil (Bendíková 2016b).

The school through the education process of the physical and sport education in qualitative and quantitative terms has one of decisive positions in influencing the physical preferences of the pupils, even in a later period of life (Telama \& Yang 2000; Cuddihy et al. 2002; Müller et al. 2008; Antala 2009; Cardon et al. 2012; Dobay 2015; Rozim \& Marko 2015; Madarász \& Bácsné 2016; Nagy \& Müller 2016a,b; Szőköl 2015).

Economic calculations show that investing of 1 euro into the physical and sport education for children and youth in schools will save 3 euros in a future, needed for a treat of the health disorders and civilization diseases, resulting from the physical inactivity (Klein, Hardman 2008).

\section{Aim}

To find out the realization of the physical activity of respondents in a monitored group in relation to their health, as well as a factor that is involved in a transfer of the physical activity to the adulthood.

\section{Methods}

\section{Participants and procedure}

The monitored group consisted of 742 respondents of the middle-aged adults from the Southern Districts of Slovakia (Komárno, Nové Zámky and Dunajská Streda), of which 403 were the women and 339 were the men as the selection was deliberate. The educational level of the respondents was secondary and academic, where all of the respondents were actively working in private and national spheres. None of the respondents was partially or totally retirement based on disability. At the same time, everyone was in marriage (with 1 and maximal 3 children). The primary characteristic of the monitored group is presented in table 1. The empirical research was conducted in 2014, by three primary stages, through distribution and collection of questionnaire data, which core was to process and evaluate qualitative and quantitative results, followed by presented interpretations. 
Table 1

Characteristics of the monitored group $(n=742)$

\begin{tabular}{|c|c|c|c|c|}
\hline Monitored group & $\mathbf{n}$ & $\begin{array}{c}\text { Age } \\
\text { (years) }\end{array}$ & $\begin{array}{c}\text { Height } \\
{[\mathbf{c m}]}\end{array}$ & $\begin{array}{c}\text { Weight } \\
{[\mathbf{k g}]}\end{array}$ \\
\hline Women & 403 & $37.2 \pm 3.04$ & $167.9 \pm 3.2$ & $65.3 \pm 6.8$ \\
\hline Men & 339 & $36.5 \pm 4.54$ & $179.6 \pm 6.3$ & $89.1 \pm 7.9$ \\
\hline
\end{tabular}

\section{Measurement taking}

In terms of methods of data acquisition, a method of content analysis of the study of literary sources of various important foreign and domestic databases, as well as an interrogative method, so-called "Egészség és mozgás" - "Health and Movement", anonymous, standardized questionnaire, which consisted of 60 questions, was used. The stated questionnaire was based on the stated primary monitored determinants of quality of life and lifestyle of the monitored group: primary, personal information, area of the health, area of the physical activity, area of lifestyle and risk factors.

(Note: The stated questionnaire was published under the title SF-36: -Health Survey Questionnaire Short Form in 1992. The questionnaire was expanded in 1995 and 1996, as well as prepared and expanded to analyze the physical activity under the title IPAQ Short Last: -International Physical Activity Questionnaire, which was in 2003.)

\section{Data analyses}

The obtained data were processed by percentage frequency analysis (\%) and ChiQuadrate-Test of a good match $\left(\chi^{2} \mathrm{p}<0.01, \mathrm{p}<0.05\right)$, which was followed by the evaluation of the significance differences in the answers on the individual questions in the questionnaire, between the genders, as well as Pearson Correlation Coefficient $(\mathrm{r} p<0.01, \mathrm{p}<0.05)$ to evaluate the relationship between the selected, monitored determinants among the monitored group, with an usage of Cohen Table. We also used the methods of logical analysis and synthesis, with usage of the inductive and deductive techniques and comparisons.

\section{Results}

Beginning with the aim, we present part of the results, which are a subject for further, exact processing. The presented results cannot be generalized but it is necessary to understand them in their overall context as orientative and basic, from the point of view of the health prevention (Dobay \& Bendíková 2016). 
The realization of the free time physical activities of the adults is currently a rarity because of their busyness. In the monitored group, significantly $(\mathrm{p}<0.01)$ even $56.3 \%(\mathrm{n}=$ $191, \chi^{2}=103.2323$, df-4) of the men and only $31 \%(n=125)$ of the women mentioned that like to do the physical activities in their free time as a way of active rest, whereas $7.4 \%(\mathrm{n}=$ $25)$ of the men and $22.8 \%(\mathrm{n}=92)$ of the women do not like to do any of the mentioned and do not care about it (3.2\%; $\mathrm{n}=13$ of the women; $9.1 \%, \mathrm{n}=31$ of the men). The mentioned physical activities are not done by up to $14.4 \%(\mathrm{n}=58)$ of the women and only $1.5 \%(\mathrm{n}=5)$ of the men, while rather $28.5 \%(n=115)$ of the women and $25.7 \%(n=87)$ of the men like to do the physical activities. The positive fact is that within the monitored group of the men, up to $91.1 \%(\mathrm{n}=309)$ are trying to devote to the physical activities in their leisure time. Among the women, it is about one-third less $(62.7 \%, \mathrm{n}=253)$.

The structure of the leisure time physical interests within the monitored group of the women points to a stability, especially in the most popular and less popular physical activities realized in the leisure time. From the various physical activities, the women are particularly interested in various forms of dance, such as aerobics $(16.45 \%, \mathrm{n}=114)$, zumba $(13.71 \%, \mathrm{n}$ $=95)$ and pilates $(4.47 \%, n=31)$, as well as health activities based on the spine $(8.08 \%, n=$ $56)$ and the physical activities of the health character for relaxation in general $(8.8 \%, \mathrm{n}=61)$. Among the women are thus dominated the physical activities, which are focused on their aesthetic perception of the movement and are characteristic from a psychological point of view. The other physical activities within the active rest include a swimming $(12.12 \%, \mathrm{n}=$ 84 ) and running $(11.11 \%, \mathrm{n}=77)$, which are offered in relation to the environment. A cycling $(13.85 \%, \mathrm{n}=96)$ also belongs to the very popular type of physical activity among the women. Among the monitored group of the men, the most popular and performed physical activities in the leisure time include a football (soccer) $(16.74 \%, \mathrm{n}=107)$, strengthening $(15.49 \%, \mathrm{n}=99)$, cycling $(15.34 \%, \mathrm{n}=98)$, running $(13.93 \%, \mathrm{n}=89)$ and swimming $(12.05$ $\%, \mathrm{n}=77)$. Less popular physical activities are a basketball $(6.73 \%, \mathrm{n}=43)$, tennis $(5.16 \%$, $\mathrm{n}=33)$, walking (Nordic Walking) $(4.85 \%, \mathrm{n}=31)$, volleyball $(4.85 \%, \mathrm{n}=31)$ and skating $(4.69 \%, \mathrm{n}=30)$. The findings point to and confirm the fact that the women tend to look for the physical activities of an individual character, mainly of aesthetic focus, without direct contact $\left(\chi^{2}=33.2323, \mathrm{p}<0.01\right)$, while the men prefer dynamic and conditioned physical activities $\left(\chi^{2}=36.3239, \mathrm{p}<0.01\right)$.

A frequency of performed physical activities among the monitored group of respondents was the following (table 1). $33 \%(n=112)$ of the men and $28.5 \%(n=115)$ of the women performed physical activities irregularly, while $21.5 \%(n=73)$ of the men and 
$15.6 \%(n=63)$ do not perform any physical activities at all. On the other hand, performing the physical activities more than 3 times a week was done by $9.4 \%(n=32)$ of the men and $5.2 \%(\mathrm{n}=21)$ of the women with $4.2 \%$ of the difference in the women's disadvantage. Performing the physical activities 1 time a week was done by $29.2 \%(n=99)$ of the men and $23.3 \%(n=94)$ of the women $(5.9 \%$ of the difference in the women's disadvantage $)$. Significantly $\left(\chi^{2}=57.3878, \mathrm{p}<0.01\right.$, df-5) up to $20.1 \%(\mathrm{n}=81)$ of the women performed physical activities regularly, 2 times a week, while performing the physical activities 3 times a week was done by $7.2 \%(n=29)$ of the women. The men with $0.3 \%$ of the difference performed the physical activities 2 times a week $(3.5 \% ; n=12)$ and 3 times a week $3.2 \%(n$ $=11)$.

Table 1

The frequency of physical activity $(n=742)$

\begin{tabular}{|l|c|c|c|c|c|c|c|c|c|c|c|c|}
\hline $\begin{array}{l}\text { Frequency of } \\
\text { Phys. activity }\end{array}$ & \multicolumn{2}{|c|}{$\begin{array}{l}\text { does not } \\
\text { practice }\end{array}$} & \multicolumn{2}{|c|}{ irregularly } & \multicolumn{2}{|c|}{$\begin{array}{c}\text { once a } \\
\text { week }\end{array}$} & \multicolumn{2}{|c|}{$\begin{array}{c}\text { twice a } \\
\text { week }\end{array}$} & \multicolumn{2}{|c|}{$\begin{array}{c}\text { 3 times } \\
\text { a week }\end{array}$} & \multicolumn{2}{c|}{$\begin{array}{c}\text { more than 3 } \\
\text { times a week }\end{array}$} \\
\hline $\begin{array}{l}\text { Sex/ } \\
\text { multiplicity }\end{array}$ & $\mathrm{n}$ & $\%$ & $\mathrm{n}$ & $\%$ & $\mathrm{n}$ & $\%$ & $\mathrm{n}$ & $\%$ & $\mathrm{n}$ & $\%$ & $\mathrm{n}$ & $\%$ \\
\hline $\begin{array}{l}\text { womem } \\
(\mathrm{n}=403)\end{array}$ & 63 & 15.6 & 115 & 28.5 & 94 & 23.3 & 81 & 20.1 & 29 & 7.2 & 21 & 5.2 \\
\hline $\begin{array}{l}\text { men } \\
(\mathrm{n}=339)\end{array}$ & 73 & 21.5 & 112 & 33.0 & 99 & 29.2 & 12 & 3.5 & 11 & 3.2 & 32 & 9.4 \\
\hline$\chi^{2}$ & & & & & \multicolumn{6}{|c|}{$57.3878, \mathrm{p}<0.01$} \\
\hline
\end{tabular}

An intensity of physical activities is very important from the point of view of the health of human beings, as well as the above mentioned frequency. That is why we were interested in the fact. Similarly, among the men $(52.2 \%, \mathrm{n}=177)$ and women $(49.1 \%, \mathrm{n}=$ 198) dominated the median intensity of physical activities. At the same time, the men $30.7 \%$ $(n=104)$ were reported with the high intensity and only $17.1 \%(n=58)$ were with the low intensity of physical activities. For the women, the situation was the opposite. The low intensity was dominated by $35.2 \%(\mathrm{n}=142)$ and the high intensity of the physical activities was only in $15.6 \%(n=63)$. We observed the significant difference $\left(\chi^{2}=41.309, p<0.01\right.$, df2 ) among the genders at the low intensity of performed physical activities (table 2).

From the point of view of a time volume, which the respondents devoted to the physical activities, we found that the highest percentages among the women $(46 \%, \mathrm{n}=189)$ represented the physical activity in a duration of 60 minutes, while the men performed the 
physical activities significantly over 1 hour $(37.1 \%, \mathrm{n}=126)\left(\chi^{2}=60.0832, \mathrm{p}<0.01, \mathrm{df}-4\right)$ (table 3).

Table 2

Intensity of physical activity $(n=742)$

\begin{tabular}{|l|c|c|c|c|c|c|}
\hline Intensity physical activity & \multicolumn{2}{|c|}{ high intensity } & \multicolumn{2}{c|}{ medium intensity } & \multicolumn{2}{c|}{ low intensity } \\
\hline Sex/multiplicity & $\mathrm{n}$ & $\%$ & $\mathrm{n}$ & $\%$ & $\mathrm{n}$ & $\%$ \\
\hline womem $(\mathrm{n}=403)$ & 63 & 15,6 & 198 & 49,1 & 142 & 35,2 \\
\hline men $(\mathrm{n}=339)$ & 104 & 30,7 & 177 & 52,2 & 58 & 17,1 \\
\hline$\chi 2$ & \multicolumn{6}{|c|}{$41.309, \mathrm{p}<0.01$} \\
\hline
\end{tabular}

Table 3

The volume of physical activity in adults $(n=742)$

\begin{tabular}{|l|c|c|c|c|c|c|c|c|c|c|}
\hline The time volume & \multicolumn{2}{|c|}{$\mathbf{1 5}$ min } & \multicolumn{2}{c|}{30 min } & \multicolumn{2}{c|}{$\mathbf{4 5}$ min } & \multicolumn{2}{c|}{ 60 min } & \multicolumn{2}{c|}{ more than 60 min } \\
\hline Sex/ multiplicity & $\mathrm{n}$ & $\%$ & $\mathrm{n}$ & $\%$ & $\mathrm{n}$ & $\%$ & $\mathrm{n}$ & $\%$ & $\mathrm{n}$ & $\%$ \\
\hline womem $(\mathrm{n}=403)$ & 36 & 8,9 & 67 & 16,6 & 59 & 14,6 & 189 & 46,8 & 52 & 12,9 \\
\hline men $(\mathrm{n}=339)$ & 26 & 7,6 & 42 & 12,3 & 33 & 9,7 & 112 & 33 & 126 & 37,1 \\
\hline$\chi 2$ & \multicolumn{10}{|c|}{$60.0832, \mathrm{p}<0.01$} \\
\hline
\end{tabular}

The way of performing the physical activities among the monitored group, both the men $(68 \%, \mathrm{n}=231)$ and the women $(53 \%, \mathrm{n}=214)$ with the highest percentage representation labelled the answer "in an organized group", significantly $(p<0.01)$ in favor of the men $(\chi 2=22.3299$, df-3). The answer "in a nonorganized group" labelled $20 \%(n=67)$ of the men and $25 \%$ of the women $(n=101)$. Only $7 \%(n=24)$ of the men and $9 \%(n=36)$ of the women labelled the answer, "Individually," while the answer "I do not care" was chosen by $5 \%(n=17)$ of the men and $13 \%(n=52)$ of the women.

Significantly more men $\left(45.7 \% ; \mathrm{n}=155, \chi^{2}=177.8421, \mathrm{p}<0.01 ; \mathrm{df}-4\right)$ than women $(12.2 \%, n=49)$ evaluated their health "excellent". $29.2 \%(n=99)$ of the men and $17.1 \%(n$ $=69)$ of the women labelled the answer "very good". $36.5 \%(n=147)$ of the women and 19.2 $\%(n=65)$ of the men rated their health as "good," while $2.7 \%(n=9)$ of the men and $8.2 \%$ $(n=33)$ of the women rated it negatively. "Not good" was reported in $3.2 \%(n=11)$ of the men and $26.1 \%(n=105)$ of the women.

The higher percentage representation and significantly $(\mathrm{p}<0.01)$ more men $(54.9 \%, \mathrm{n}$ $=187)$ than women $(21.6 \%, \mathrm{n}=87)$ reported that they had no health problems $(33.3 \%$ difference in favor of the men; $\chi^{2}=132.1577$, df-3). On the contrary, the health problems had $10.9 \%(n=37)$ of the men and $26.8 \%(n=108)$ of the women. The answer "more less, no," 
was reported more $(28.6 \%, \mathrm{n}=97)$ among the men than the women $(23.8 \%, \mathrm{n}=96)$. At the higher percentage representation, the answer "mostly yes" was picked $27.8 \%(n=112)$ of the women and $5.6 \%(n=19)$ of the men. This suggests that the men had fewer health problems than the women. Among the men, we found the relationship between the physical activity and evaluation of the health status $(\mathrm{r}=0.9420)$, which means that those who performed the physical activities also rated their health better (men vs. women). Even the feeling of the good health was significantly $(\mathrm{p}<0.01)$ more among the men $\left(52.8 \% ; \mathrm{n}=179, \chi^{2}=31.7832\right.$, df-3) than the women $(37.7 \%, \mathrm{n}=152)$, with $15.1 \%$ of the difference in the women's disadvantage. In the same way, we also found among the men the relationship between the performed physical activity and feeling of health $(\mathrm{r}=0.8921)$ but also between the health problems and feeling of health $(r=0.739)$, as well as the women $(r=0.6714)$.

A physical fitness $31.5 \%(n=107)$ of the men and $9.6 \%(n=39)$ of the women was rated as "excellent", with $21.9 \%$ significant difference $(\chi 2=103.84, p<0.01$, df- 4$)$ in men's advantage, while "very bad" was reported more among the women $(22.1 \%, n=89)$ than the men $(5.3 \%, n=18) .29 .1 \%$ of the men and $24.6 \%$ of the women labelled the answer "good" condition", while "satisfactory" was reported in $32.3 \%$ of the women and $13.2 \%$ of the men. $20.9 \%$ of the men and $11.4 \%$ of the women picked the answer "quite good". Based on our findings, we found the relationship between the health status and physical fitness among the men $(r=0.8300)$, as well as the women $(r=0.7193)$.

Currently, significantly more $\left(\chi^{2}=33.6871, \mathrm{p}<0.01\right.$, df-4) of the men, up to $50.4 \%$ (n $=171)$ and only $3 \%$ of the women $(n=121)$ reported the answer "yes" and perceived the physical activities as a significant factor of the health. The men, at the same time, perceived the importance of the physical activities, in terms of their health status $(r=0.8791)$ much more intense than the population of women in the monitored group. While, the women reported the answer "rather yes", in $40.4 \%(n=163)$ and $29.8 \%(n=101)$ of the men, this means $70.4 \%(n=284)$ of the women and $80.2 \%(n=272)$ of the men had positive perception of these factors for the health of human beings On the other hand, $12.7 \%(\mathrm{n}=51)$ of the women and $9.7 \%(n=33)$ of the men, do not paid the attention to the importance of the mentioned facts. "Rather not" was chosen by $13.6 \%(\mathrm{n}=55)$ of the women and $7.4 \%(\mathrm{n}$ $=25)$ of the men and "was one" was chosen by $2.7 \%(n=9)$ of the men and $3.2 \%(n=13)$ of the women. At the same time, the men perceived the evaluation and level of their physical condition through the importance of performing physical activities $(r=0.791)$.

A retrospective view of the respondents on the importance of physical and sport education in their lives pointed to the fact that significantly $(p<0.01)$ found that the women 
perceived the importance of physical education in health at $35.2 \%(n=142)(\chi 2=26.2498)$, while the men from the point of view of creation of the relation to the physical activities was $28.9 \%(\mathrm{n}=98)$ and performance in $26.3 \%$. The answer "creation of relation to the physical activities" was reported only in $27.5 \%(n=111)$ of the women. It means that the women perceived the physical and sport education through the health, while the men through the creation of relation to the physical activities, which they are performed within the active rest, even currently $(56.3 \%, \mathrm{n}=191)$ than the women $(31 \%, \mathrm{n}=125)$.

The popularity of physical and sport education among the respondents of both genders also confirmed our expectations, where only one third $(30 \%, n=121)$ of the women enjoyed physical and sports education, while among the men it was more significantly $(\chi 2=37.5297$, $\mathrm{p}<0.01$, df-3), even up to $51.6 \%(\mathrm{n}=175)$, with $21.6 \%$ of the difference of the men's advantage. $30.5 \%(n=123)$ of the women did not like the physical and sport education, as well as $18 \%(\mathrm{n}=61)$ of the men, which is $12.5 \%$ less. The answer "sometimes" was picked up by $22.8 \%(\mathrm{n}=92)$ of the women and $17.1 \%(\mathrm{n}=58)$ of the men. The laxity of the popularity of the mentioned subject was reported by $16.6 \%(n=67)$ of the women and 13.3 $\%(n=45)$ of the men.

In the same was, the popularity of physical and sport education, even the activity of respondents in the physical and sport education classes was significantly higher among the men $\left(\chi^{2}=26.9684, \mathrm{p}<0.01, \mathrm{df}-3\right)$ than the women. Being active in the physical and sport education classes was $41.6 \%(n=141)$ of the men and only $27.5 \%(n=111)$ of the women, while $16.8 \%(\mathrm{n}=57)$ of the men and $15.1 \%(\mathrm{n}=61)$ of the women were considered as inactive. "Rather active" was $40.9 \%(\mathrm{n}=165)$ of the women and $34.8 \%$ of the men $(\mathrm{n}=$ 118). $6.8 \%(\mathrm{n}=23)$ of men and $16.4 \%(\mathrm{n}=66)$ of the women were included in the group "rather not" active. It mentioned means that the men enjoyed the physical and sport education classes, as well as actively participated $(r=0.8363)$, not as the women. Compared to current findings, it is very similar, boys are more active than girls.

\section{Discussion}

Our findings point to a number of facts and relationships between a human health and a realization of a physical activity in relation to a lifestyle. If in the past the physical activity had limited a strength, a speed and an endurance, we would need it as a factor of a survival and a balance between a physical and a mental determinants of maintaining an active health. 
Therefore, in this context, it is necessary to show on politics of Health 2020, which is based on four priority areas, where each one focuses on investments to the health through a life cycle and creation of opportunities for strengthening responsibilities of citizens for their own health, which is directly confirmed in our findings and pointed to an educational transfer towards the health through the physical activity as a suitable form of a prevention. It means that well-chosen and realized physical activity aimed at promoting the right lifestyle and the responsibility of human beings for their health as can help to manage epidemic of so-called civilization diseases (obesity, oncological diseases, cardiovascular diseases, hypertension, skeletal disorders, metabolic diseases, etc.). Such seemingly not medical, but public health measures will help to prevent a growth of the new civilization diseases and to improve a current state of the human health because the physical activities are by their content, extent and influence of complex biological, psychological and social, as well as cultural health phenomenon.

\section{Conclusion}

Based on the aim of the current study, we found that:

- the relationship between the health status and fitness among the men $(r=0.8300)$ and among the women $(r=0.7193)$,

- the relationship between performed physical activity and feeling of health $(r=0.8921)$ but also between the health problems and feeling of health among the men $(r=0.739)$, as well as among the women $(\mathrm{r}=0.6714)$,

- the men at the same time perceived the importance of physical activity, in terms of their health $(\mathrm{r}=0.8791)$ much more intense than the women,

- the men perceived the evaluation and level of their physical condition through the importance of performing the physical activity $(r=0.791)$.

From the point of view of the health, we strongly confirm the difference in the health status ratings among the men, where we confirm the relationship between the physical activity and health status, as well as the physical activity and fitness among the men. Significantly, we confirm the difference performing of the physical activities among the genders, in terms of the frequency, intensity, volume and content. The physical and sport education plays the 
significant role among the men in the transfer of physical activity from the school environment to the adulthood.

\section{References}

1. ANTALA, B., 2009. Healthy life style as a part of PE school curriculum. In: Book of abstrakt., 5th FIEP European congress. Niš: University of Nis, p. 46.

2. BÁCSNÉ, B. É., 2015. Sportszervezetek müködési kereteinek változása. In: KözépEurópai Közlemények VIII., 1(28), pp. 151-161.

3. BENDÍKOVÁ, E., 2014. Lifestyle, physical and sports education and health benefits of physical activity. In: European researcher: international multidisciplinary journal. 69(22), pp. 343-348.

4. BENDÍKOVÁ, E., 2016a. Curricular transformation of education in the field of physical and sport education in Slovakia. In: European Journal of Contemporary Education. 18(4), pp. 410-417.

5. BENDÍKOVÁ, E., 2016b. Changes in the posture of students due to equipment-aided exercise programs that are applied in physical and sport education. In: Journal of Physical Education and Sport. 16(2), pp. 281-286.

6. BENDÍKOVÁ, E., R. R. UVINHA \& M. MARKO, 2016. Pain as manifestation of functional disorders of musculoskeletal system. In: Sport Science. 9(1), pp. 90-95.

7. BLAIR, S. N., S. G. DAVEY, I. M. LEE, K. FOX, M. HILLSDON, R. E. MCKEOWN, W. L. HASKELL \& M. MARMOT, 2010. Atribute to Professor Jeremiah Morris: the Man Who Invented the Field of Physical Activity Epidemiology. In: Ann Epidemiol. 20(9), pp. 651-660.

8. BORBÉLY, A. \& A. MÜLLER, 2008. A testi-lelki harmónia összefüggései és módszertana. Budapest: Professzorok az Európai Magyarországért Egyesület. 211 p.

9. CARDON, G. M., R. V. ACKER, J. SEGHERS, K. De MARTELAER, L. L. HAERENS \& I. M. M. De BOURDEAUDHUIJ, 2012. Physical activity promotion in schools: which strategies do schools (not) implement and which socioecological factors are associated with implementation? In: Health education research. 27(3), pp. 470-483. 
10. CORBIN, C. B. \& R. P. PANGRAZI, 2003. Guidelines for Appropriate Physical Activity for Elementary School Childern. Update. Reston, VA : NASPE Publications.

11. CUDDIHY, T. F., C . B. CORBIN \& D. DALE, 2002. A short instrument for assessing intrinsic motivation for physical acivity. In: Physical Educator. 59(1), pp. 26-37.

12. DOBAY, B., 2015. Az iskolai sporttanfolyamok motivációs hatása a felnöttkori rekreációs sporttevékenységekre Dél-Szlovákiában. Komárom: Kompress Kiadó, 90 p.

13. DOBAY, B. \& E. BENDÍKOVÁ, 2016. Pohybová aktivita v životnom štýle dospelých z hl'adiska zdravia. [The physical activity in adults lifestyle in terms of health]. Komárom: Kompress, $104 \mathrm{p}$.

14. GURÍN, D., J. HUDÁK \& Š. TOMKOVÁ, 2015. Vplyv posturálneho tréningu bránice na funkčnú kapacitu plúc. In: Nové trendy ve zdravotnícke praxi. Sborník z 6. Mezinárodní konference, Zlín, pp. 133-138.

15. KLEIN, G. \& K. HARDMAN, 2008. Physical Education and Sport Education in European Union. Editions Revue EPS. Paris, 454 p.

16. MADARÁSZ, T. \& B. É. BÁCSNÉ, 2016. Survey on the Employees' Fitness Condition and the Employers' Health Preservation Possibilities in Case of Small and Medium-sized Enterprises. In: Sea: Practical Application of Science. IV, 2 (11), pp. 205-212.

17. MÜLLER, A., E. KÖNYVES, T. VÁRHELYI \& A. MONDOK, 2008. Új utakon a testnevelő tanárképzés Egerben - A sportszakos hallgatók utazási szokásainak, és a sítáborozás kínálati elemeivel való elégedettségének vizsgálata. In: Economica. (1), pp. 85-95.

18. NAGY, Z. \& A. MÜLLER, 2016a. The role of the pulse measurement in the students' differentiated education applied in PE. In: Physical Activity, Health and Prevention: International Scientific Conference. B. Bystrica : UMB, pp. 5-14.

19. NAGY, Z. \& A. MÜLLER, 2016b. The quantification of derivation in the volleyball thematic unit. In: Trendek és eredmények a biológiai kutatás és oktatás terén. Komárno: Selye János Egyetem Tanárképző Kara, pp. 55-62.

20. NEMČEK, D., 2016. Quality of life of people with disabilities from sport participation point of view. In: Acta Facultatis Educationis Physicae Universitatis Comenianae. 56(2), pp. 77-92.

21. NEMČEK, D. \& A. SIMON, 2016. Effect of 3-months home-based exercise program on changes of cognitive functioning in older adults living in old people's home. In: Acta Facultatis Educationis Physicae Universitatis Comenianae. 56(1), pp. 16-29. 
22. NEMČEK, D., 2017a. Self-esteem in people with physical disabilities: Differences between active and inactive individuals. In: Acta Facultatis Educationis Physicae Universitatis Comenianae. 57(1), pp. 34-47.

23. NEMČEK, D., 2017b. Subjective quality of life analyses in sedentary population with different health status. In: International Journal of Arts Humanities and Social Sciences. 2(7), pp. 25-33.

24. NOWAK, M., 1997. Chosen aspects of healthrelated behaviour of women who retained physical fitness in the past. Women and Sport. Proceedings of XIII. IAPESGW Congress, Gdans. pp. 131-138.

25. PATE, R. \& J. O’Neill, 2008. The evolving definition of "sedentary". In: Exercise \& Sport Sciences Reviews. 36(4), pp. 173-178.

26. PEDERSEN, B. K., 2009. The diseasome of physical inactivity-and the role of myokines in muscle-fat cross talk. In: The Journal of Physiology. 587(Pt 23), pp. 5559-5568.

27. PRASAD, D. S. \& B. C. DAS, 2009. Physical inactivity: A cardiovascular risk factor. In: Indian Journal of Medical Science. 63(1), pp. 33-42.

28. ROZIM, R. \& M. MARKO, 2015. Motivačné aktivity vo vyučovaní telesnej výchovy u študentov stredných škôl v Žilinskom regióne. In: Pohyb a kvalita života. Zborník príspevkov z medzinárodnej konferencie. Nitra: Equilibria, s.r.o., pp. 96-105.

29. SZÖKÖL, I., 2015. Quality management system in educational process. In: 8th International Conference of Education, Research and Innovation. Seville (Spain): IATED Academy, 2015, pp. 7282-7285.

30. SZÖKÖL, I., 2016. Educational evaluation in contemporary schools. Szeged: Belvedere Meridionale, $159 \mathrm{p}$.

31. TELAMA, R. \& YANG. X., 2000. Decline of physical activity from youth to young adulthood in Finland. In: Medicine \& Science in Sports \& Exercise. 32(9), 1617-1622.

32. TOMKOVÁ, Š. \& I. PALAŠČÁKOVÁ-ŠPRINGROVÁ, 2013. Kinesiotape a jeho vplyv na korekciu päty u adolescentov. In: Fyzioterapia, Regenerácia a Šport, recenzovaný zborník vedeckých prác. Trenčín: Trenčianska univerzita Alexandra Dubčeka, Fakulta zdravotníctva, pp. 124-127.

33. WORLD HEALTH ORGANIZATION (WHO), 2005. Preventing chronic diseases and vital investment, $182 \mathrm{p}$. 